\title{
Epidural Analgesia Kolaborasi Dokter Anestesi dan Dokter Bedah Syaraf untuk Penanganan Nyeri Pascaoperasi Tulang Belakang
}

\section{Epidural Analgesia Collaboration of Anesthetists and Neurosurgeons for Postoperative Pain of Spinal Surgery}

Doso Sutiyono

*Departemen Anestesiologi dan Terapi Intensif, Fakultas Kedokteran, Universitas Diponegoro/ RSUP Dr. Kariadi, Semarang, Indonesia

${ }^{\square}$ Korespondensi: dososutiyono@fk.undip.ac.id

\begin{abstract}
Background: Postoperative pain is still a major problem for postoperative patients and become responsibility of the anesthetist and surgeon. Spinal surgery causes severe postoperative pain. Epidural analgesia results in lower pain scores and fewer rescue analgesic requirements than conventional systemic analgesia in spinal surgery. This case report aims to introduce epidural analgesia for the management of pain in spinal surgery at Dr. Kariadi Hospital Semarang. We report two cases of postoperative pain management of patients with spinal surgery with major capital epidural analgesia which is the result of collaboration between anesthetists and neurosurgeons.

Case: Patient 1 was suffering from inferior flacid paraplegi due to a T11 - T12 compression fracture, patient 2 had a hernia nucleus pulposus (HNP) L4 - L5, L5 - S1. Both underwent spinal surgery. Near the end of the operation, the neurosurgeon places an epidural catheter in the epidural space. After the wound is closed, bupivacaine $0.125 \%$ $10 \mathrm{ml}$ bolus is injected through an epidural catheter shortly after the patient is stretched. Postoperative pain is managed by giving $0.125 \%$ continuous bupivacaine. Patients also get paracetamol 1000 mg every 6 hours.

Discussion: Epidural analgesia for spinal surgery can be given before surgery, during surgery, or at the end of surgery. The injected drug can be a local anesthetic drug, opioid, or a combination. Drug administration can be in the form of a single bolus, continuous infusion, or patient control epidural analgesia (PCEA). Some of the benefits include lower pain scores, less need for opioids, faster intestinal peristalsis recovery, lower incidence of nausea, vomiting, less blood loss from surgery, and higher levels of patient satisfaction.

Epidural analgesia to relieve postoperative spinal pain is an effective and safe method. This technique can be used in all types of spinal operations such as microdisectomy, laminectomy, instrumentation with or without correction, and correction of scoliosis.

From the case reports, postoperative condition of the two patients was stable with no complaints. Numeric rating scale (NRS) for 48 hours postoperative $\leq 2$. Hemodynamically stable. No side effects were found.
\end{abstract}

Volume 11, Nomor 3, Tahun 2019 
Conclusion: Administration of an epidural catheter towards the end of the operation ensures that the epidural catheter is placed in the right location. Epidural analgesia in spinal surgery has been shown to be effective in managing postoperative pain.

Keywords: epidural anelgesia; epidural catheter; HNP; postoperative pain; spinal surgery

\begin{abstract}
ABSTRAK
Latar Belakang: Nyeri pascaoperasi masih merupakan masalah utama pasien pascaoperasi dan menjadi tanggung jawab bersama dokter anestesi dan dokter bedah. Operasi tulang belakang menyebabkan nyeri pascaoperasi yang berat. Epidural analgesia menghasilkan skor nyeri lebih rendah dan kebutuhan rescue analgetic lebih sedikit dibanding analgesia konvensional sistemik pada operasi tulang belakang.

Laporan kasus ini bertujuan memperkenalkan epidural analgesia untuk penanganan nyeri operasi tulang belakang di RSUP Dr. Kariadi Semarang. Kami laporkan dua kasus penanganan nyeri pascaoperasi pasien yang operasi tulang belakang dengan modal utama epidural analgesia yang merupakan hasil kolaborasi dokter anestesi dan dokter bedah syaraf.
\end{abstract}

Kasus: Pasien 1 menderita paraplegi inferior flacid karena fraktur kompresi T11 - T12, pasien 2 menderita hernia nucleus pulposus (HNP) L4 - L5, L5 - S1. Keduanya menjalani operasi tulang belakang. Menjelang akhir tindakan operasi, dokter bedah syaraf memasang kateter epidural di ruang epidural. Setelah luka operasi ditutup, bupivakain $0,125 \%$ bolus $10 \mathrm{ml}$ disuntikan lewat kateter epidural sesaat setelah pasien ditelentangkan. Nyeri pascaoperasi dikelola dengan memberikan bupivakain $0,125 \%$ kontinyu. Pasien juga mendapatkan paracetamol $1000 \mathrm{mg}$ tiap 6 jam.

Pembahasan: Epidural analgesia untuk operasi tulang belakang dapat diberikan sebelum operasi, selama operasi, atau akhir operasi. Obat yang diinjeksikan dapat merupakan obat lokal anestesi, opioid, atau kombinasinya. Pemberian obat dapat berupa bolus tunggal, infus kontinyu, atau patient control epidural analgesia (PCEA). Beberapa keuntungan yang didapat berupa skor nyeri yang lebih rendah, kebutuhan opioid lebih sedikit, pemulihan peristaltik usus yang lebih cepat, insiden mual muntah lebih rendah, kehilangan darah durante operasi lebih sedikit, dan tingkat kepuasan pasien lebih tinggi. Epidural analgesia untuk menghilangkan rasa nyeri pascaoperasi bedah tulang belakang merupakan metode efektif dan aman. Teknik ini dapat digunakan di semua jenis operasi tulang belakang seperti mikrodisektomi, laminektomi, instrumentasi dengan atau tanpa koreksi, dan koreksi skoliosis.

Pada pasien kasus didapatkan pascaoperasi kondisi ke dua pasien stabil tak ada keluhan. Numeric rating scale (NRS) selama 48 jam pascaoperasi $\leq 2$. Hemodinamik stabil. Efek samping tindakan tidak ditemukan.

Kesimpulan: Pemasangan kateter epidural menjelang akhir operasi memastikan kateter epidural ditempatkan pada lokasi yang tepat. Epidural analgesia pada operasi tulang belakang terbukti efektif mengelola nyeri pascaoperasi.

Kata Kunci: epidural anelgesia; epidural kateter; HNP; nyeri pascaoperasi; operasi tulang belakang 


\section{PENDAHULUAN}

Nyeri pascaoperasi masih merupakan masalah utama bagi penderita pascaoperasi. Nyeri akut yang tidak terkontrol pascaoperasi dikaitkan dengan ketidakpuasan pasien, komplikasi pascaoperasi, dan merupakan faktor risiko untuk berkembang menjadi nyeri kronis. Semakin kuat intensitas dan lama durasi nyeri, makin memperburuk kualitas hidup penderita, menghambat kesembuhan dan memperlama masa perawatan di rumah sakit, sehingga pengelolaan nyeri yang baik perlu dilakukan. ${ }^{1}$

Operasi tulang belakang termasuk operasi dengan nyeri pascaoperasi yang berat. Sumber rasa sakit setelah operasi tulang belakang disebabkan sayatan kulit, inflamasi jaringan otot, radiks dan neuron, eksisi tulang vertebra dan perangkat fiksasi internal yang bereaksi dengan jaringan. ${ }^{2}$

Operasi tulang belakang sebagian besar dilakukan dengan anestesi umum. Pengelolaan nyeri pascaoperasi biasanya dilakukan secara konvensional dengan paracetamol, NSAID, dan opioid yang digunakan sendiri atau dalam kombinasi. ${ }^{3}$

Analgesia epidural adalah pemberian obat analgesia ke dalam ruang epidural. Teknik ini memiliki beberapa keunggulan dibandingkan penggunaan opioid sistemik karena dapat mengurangi mortalitas, menurunkan insiden komplikasi dan infeksi pulmonal, menurunkan komplikasi intestinal, dan menurunkan komplikasi kardiak pascaoperasi. ${ }^{4}$

Secara umum teknik epidural analgesia menghasilkan skor nyeri lebih rendah dan kebutuhan rescue analgetic lebih sedikit dibanding analgesia konvensional sistemik pada operasi tulang belakang. ${ }^{3}$

Insersi kateter epidural biasanya dilakukan sebelum incisi operasi, tetapi dapat juga dilakukan pada akhir operasi. Pada kasus yang akan saya laporkan ini, insersi kateter epidural dilakukan di akhir operasi oleh dokter bedah syaraf sehingga diharapkan posisi kateter tepat di ruang epidural sehingga diharapkan obat menjadi lebih efektif. Pada prinsipnya pengelolaaan nyeri pascaoperasi menjadi tanggung jawab bersama dokter anestesi dan dokter bedah sehingga kolaborasi keduanya sangat berguna.

\section{KASUS}

Pada kesempatan ini saya laporkan 2 kasus pasien yang menjalani operasi tulang belakang di RSUP Dr. Kariadi Semarang. Titik berat laporan kasus ini adalah penanganan nyeri pascaoperasi dengan modal utama epidural analgesia yang merupakan hasil kolaborasi dokter anestesi dan dokter bedah syaraf.

Tabel 1. Data dasar pasien

\begin{tabular}{lcc}
\hline Hal & Pasien 1 & Pasien 2 \\
\hline Nama & Tn. T & Tn. IS \\
Umur & 51 tahun & 45 tahun \\
Berat badan & $65 \mathrm{~kg}$ & $60 \mathrm{~kg}$ \\
Tinggi badan & $160 \mathrm{~cm}$ & $165 \mathrm{~cm}$ \\
Pendidikan & SMA & S1 \\
\hline
\end{tabular}




\section{Anamnesa}

Pasien 1

Satu setengah bulan yang lalu pasien jatuh terpeleset. Pasien tidak dapat menggerakkan kedua kakinya. Rasa tebal dirasakan di kedua kaki dari jari sampai panggul. Pasien juga tidak dapat buang air besar dan buang air kecil.

Pasien 2

Sekitar 3 tahun sebelum masuk rumah sakit pasien mulai merasakan nyeri pinggang bawah hilang timbul. Pasien harus minum obat dari warung untuk menghilangkan rasa nyeri. Kelemahan anggota gerak tidak dirasakan, rasa tebal tidak ada, tidak kesemutan, nyeri tidak dijalarkan. Pasien telah berobat ke rumah sakit dan menjalani fisioterapi tetapi belum membaik.

Sejak 6 bulan yang lalu pasien mengeluh nyeri bertambah berat. Nyeri semakin bertambah bila membungkuk, mengejan, atau batuk. Nyeri berkurang saat berbaring. Nyeri dirasakan menjalar ke kaki kanan, kesemutan, dan rasa tebal di kaki kanan. Buang air besar dan buang air kecil masih tidak terganggu.

Mulai 1 minggu rasa nyeri juga dirasakan menjalar ke kaki kiri. Pasien dikirim ke rumah sakit untuk menjalani pembedahan.

Tabel 2. Anamnesis pasien preoperasi

\begin{tabular}{|c|c|c|}
\hline Hal & Pasien 1 & Pasien 2 \\
\hline Alergic & Tidak ada & Tidak ada \\
\hline Medication & $\begin{array}{l}\text { Ciprofloxacin } 400 \mathrm{mg} / 12 \mathrm{jam} \\
\text { Metilprednisolon } 62,5 \mathrm{mg} / 12 \\
\text { jam } \\
\text { Omeprazole } 40 \mathrm{mg} / 12 \mathrm{jam} \\
\text { Vit B } 121 \mathrm{amp} / 24 \mathrm{jam} \\
\text { Zink } 20 \mathrm{mg} / 24 \mathrm{jam} \\
\text { Paracetamol } 500 \mathrm{mg} / 8 \mathrm{jam}\end{array}$ & $\begin{array}{l}\text { Ketorolak } 30 \mathrm{mg} / 8 \mathrm{jam} \\
\text { Paracetamol } 500 \mathrm{mg} / 8 \mathrm{jam} \\
\text { Gabapentin } 100 \mathrm{mg} / 12 \mathrm{jam} \\
\text { Vit B1, B6, B12 } 1 \mathrm{tab} / 8 \mathrm{jam} \\
\text { Ranitidin } 50 \mathrm{mg} / 12 \mathrm{jam}\end{array}$ \\
\hline Post Illness & $\begin{array}{l}\text { Riwayat asma, kencing manis, } \\
\text { hipertensi, penyakit jantung, } \\
\text { operasi, semua disangkal. }\end{array}$ & $\begin{array}{l}\text { Riwayat asma, kencing manis, } \\
\text { hipertensi, penyakit jantung, operasi, } \\
\text { semua disangkal. }\end{array}$ \\
\hline $\begin{array}{l}\text { Last Meal } \\
\text { Event }\end{array}$ & $\begin{array}{l}6 \text { jam sebelum operasi } \\
\text { Demam, batuk pilek disangkal. } \\
\text { Kedua tungkai bawah tak bisa } \\
\text { digerakkan. } \\
\text { Tak bisa BAB dan BAK }\end{array}$ & $\begin{array}{l}6 \text { jam sebelum operasi } \\
\text { Demam, batuk pilek disangkal. } \\
\text { Nyeri pinggang hilang timbul, } \\
\text { dijalarkan sampai kaki kanan kiri. } \\
\text { Nyeri bertambah saat membungkuk, } \\
\text { mengejan, dan batuk. Nyeri berkurang } \\
\text { saat berbaring. } \\
\text { BAB dan BAK belum terganggu }\end{array}$ \\
\hline
\end{tabular}




\section{Pemeriksaan fisik}

Tabel 3. Tanda vital

\begin{tabular}{lcc}
\hline Hal & Pasien 1 & Pasien 2 \\
\hline Kesadaran & GCS 15 & GCS 15 \\
Tekanan darah & $110 / 70 \mathrm{mmHg}$ & $130 / 80 \mathrm{mmHg}$ \\
Tekanan Arteri Rerata & $83 \mathrm{~mm} \mathrm{Hg}$ & $85 \mathrm{mmHg}$ \\
Laju Jantung & $80 \mathrm{x} / \mathrm{menit}$ & $78 \times \mathrm{menit}$ \\
Laju Napas & $12 \mathrm{x} / \mathrm{menit}$ & $14 \mathrm{x} / \mathrm{menit}$ \\
Suhu & $37^{\circ} \mathrm{C}$ & $37^{\circ} \mathrm{C}$ \\
NRS & 4 & 6 \\
\hline
\end{tabular}

Keterangan:

NSR: Numeric Rating Scale

Dari pemeriksaan fisik pada kedua pasien didapatkan:

- Sistem syaraf pusat tak ada kelainan

- Kepala dan leher dalam batas normal

- Mata isokor, refleks cahaya dalam batas normal

- Toraks dan abdomen dalam batas normal.

- Punggung tidak tampak kelainan

- Ulcus dekubitus tak ada

Tabel 4. Pemeriksaan Neurologis

\begin{tabular}{|c|c|c|c|c|}
\hline \multirow[t]{2}{*}{ Hal } & \multicolumn{2}{|c|}{ Pasien 1} & \multicolumn{2}{|c|}{ Pasien 2} \\
\hline & Superior & Inferior & Superior & Inferior \\
\hline \multicolumn{5}{|l|}{ Motorik } \\
\hline Gerak & $+1+$ & $-1-$ & $+1+$ & $+1+$ \\
\hline Kekuatan & $555 / 555$ & $000 / 000$ & $555 / 555$ & $555 / 555$ \\
\hline Tonus & $\mathrm{N} / \mathrm{N}$ & Turun / Turun & $\mathrm{N} / \mathrm{N}$ & $\mathrm{N} / \mathrm{N}$ \\
\hline $\mathrm{RF}$ & $++/++$ & $+/-$ & $++/++$ & $++/++$ \\
\hline $\mathrm{RP}$ & $-1-$ & $-1-$ & $-1-$ & $-1-$ \\
\hline Sensibilitas & $\mathrm{N} / \mathrm{N}$ & $\begin{array}{l}\text { Hipestesia dari jari } \\
\text { kaki sampai } \\
\text { dermatom } T_{11}-T_{12}\end{array}$ & $\mathrm{~N} / \mathrm{N}$ & $\begin{array}{l}\text { Parestesia } \\
\text { sesuai } \\
\text { dermatom L4 - } \\
\text { L5 }\end{array}$ \\
\hline Vegetatif & Inkontinensia & urin dan alvi & $\mathrm{BAB}$ dan $\mathrm{BAK}$ & normal \\
\hline
\end{tabular}

Keterangan:

RF: Refleks Fisiologis

RP: Refleks Patologis 


\section{Pemeriksan penunjang}

Tabel 5. Hasil pemeriksaan kimia darah

\begin{tabular}{lcc}
\hline Pemeriksaan & Pasien 1 & Pasien 2 \\
\hline Darah rutin & & \\
$\mathrm{Hb}$ & $12,4 \mathrm{~g} / \mathrm{dl}$ & $13 \mathrm{~g} / \mathrm{dl}$ \\
$\mathrm{Ht}$ & $37,6 \%$ & $39,1 \%$ \\
Trombosit & $224.000 / \mu \mathrm{l}$ & $218.000 / \mu \mathrm{l}$ \\
Lekosit & $8.000 / \mu 1$ & $4.100 / \mu \mathrm{l}$ \\
Elektrolit & & \\
Kalium & $4,6 \mathrm{mmol} / 1$ & $3,8 \mathrm{mmol} / 1$ \\
Natrium & $136 \mathrm{mmol} / 1$ & $142 \mathrm{mmol} / 1$ \\
Klorida & $99 \mathrm{mmol} / 1$ & $109 \mathrm{mmol} / 1$ \\
& & \\
Gula darah sewaktu & $86 \mathrm{mg} / \mathrm{dl}$ & $83 \mathrm{mg} / \mathrm{dl}$ \\
Albumin & $3,4 \mathrm{~g} / \mathrm{dl}$ & $3,5 \mathrm{~g} / \mathrm{dl}$ \\
Ureum & $30 \mathrm{mg} / \mathrm{dl}$ & $28 \mathrm{mg} / \mathrm{dl}$ \\
Kreatinin & $0,8 \mathrm{mg} / \mathrm{dl}$ & $1,0 \mathrm{mg} / \mathrm{dl}$ \\
\hline
\end{tabular}

\section{Pemeriksaan EKG keduanya normal sinus ritme}

Tabel 6. Hasil pemeriksaan MRI

\begin{tabular}{|c|c|}
\hline Pasien 1 & Pasien 2 \\
\hline $\begin{array}{l}\text { Anterior wedge compresion fracture } \mathrm{T} 12 \\
\text { disertai bone marrow edema } \mathrm{T} 12 \text {, dan } \\
\text { retrolistesis corpus } \mathrm{T} 12 \text { yang menyebabkan } \\
\text { stenosis canalis spinalis, kompresi spinal } \\
\text { cord, dengan spinal cord contusion level } \\
\mathrm{T} 11-\mathrm{T} 12 \text {. } \\
\text { Penyempitan ruang diskus intervertebralis } \\
\mathrm{T} 11-\mathrm{T} 12 \text {. } \\
\text { Penyempitan foramen neuralis kanan kiri } \\
\text { level T11 - T12. }\end{array}$ & $\begin{array}{l}\text { Tak tampak fraktur pada vertebra lumboskral. } \\
\text { Degeneratif pada diskus intervertebralis L5 - } \\
\text { S1. } \\
\text { Bulging posterocentral pada discus } \\
\text { intervertebralis L3 - L4 dengan pendesakan } \\
\text { thecal sac tanpa penyempitan foramina } \\
\text { neuralis. } \\
\text { Protosio posterocentral pada diskus } \\
\text { intervertebralis L4 - L5, L5 - S1 dengan } \\
\text { pendesakan thecal sac disertai penyempitan } \\
\text { foramina neuralis kanan kiri setinggi level } \\
\text { tersebut. }\end{array}$ \\
\hline
\end{tabular}

\section{Diagnosis dan rencana tindakan operasi}

Tabel 7. Diagnosis dan rencana tindakan.

\begin{tabular}{lll}
\hline Hal & \multicolumn{1}{c}{ Pasien 1 } & \multicolumn{1}{c}{ Pasien 2 } \\
\hline Diagnosis & Paraplegi inferior flacid & Ichialgia bilateral \\
& Hipestesia dari jari kaki sampai & Parestesia dektra setinggi L4 - L5 \\
& setinggi T11 - T12. & HNP L4 - L5, L5 - S1. \\
& Inkontinensia urin dan alvi & Status Fisik ASA `1 \\
& Lesi transversal total medula & \\
& spinalis T11 - T12 suspek fraktur & \\
& kompresi & \\
& Status Fisik ASA 1 & Endospine Disektomy \\
Rencana Tindakan & PSRS &
\end{tabular}




\section{Manajemen anestesi}

Kedua pasien masuk ke kamar operasi terpasang infus RL dengan iv kateter nomor 20. Keadaan umum baik dengan tanda vital seperti tersebut di Tabel 3.

Premedikasi diberikan midazolam $5 \mathrm{mg}$ i.v. di meja operasi.
Induksi menggunakan propofol $2 \mathrm{mg} / \mathrm{kg}$ $\mathrm{BB}$, fentanil $100 \mu \mathrm{g}$, rocuronium $40 \mathrm{mg}$. Pemeliharaan dengan sevoflurane, fentanil drip $30 \mu \mathrm{g} / \mathrm{jam}$, dan rocuronium $10 \mathrm{mg}$ bila diperlukan.

Mode ventilator SIMV / $\mathrm{FiO}_{2} 60 \%$ / RR 12/ VT 450 / PEEP 4 / I : E rasio 1: 2

Lama operasi: pasien $1: 240$ menit, pasien $2: 180$ menit

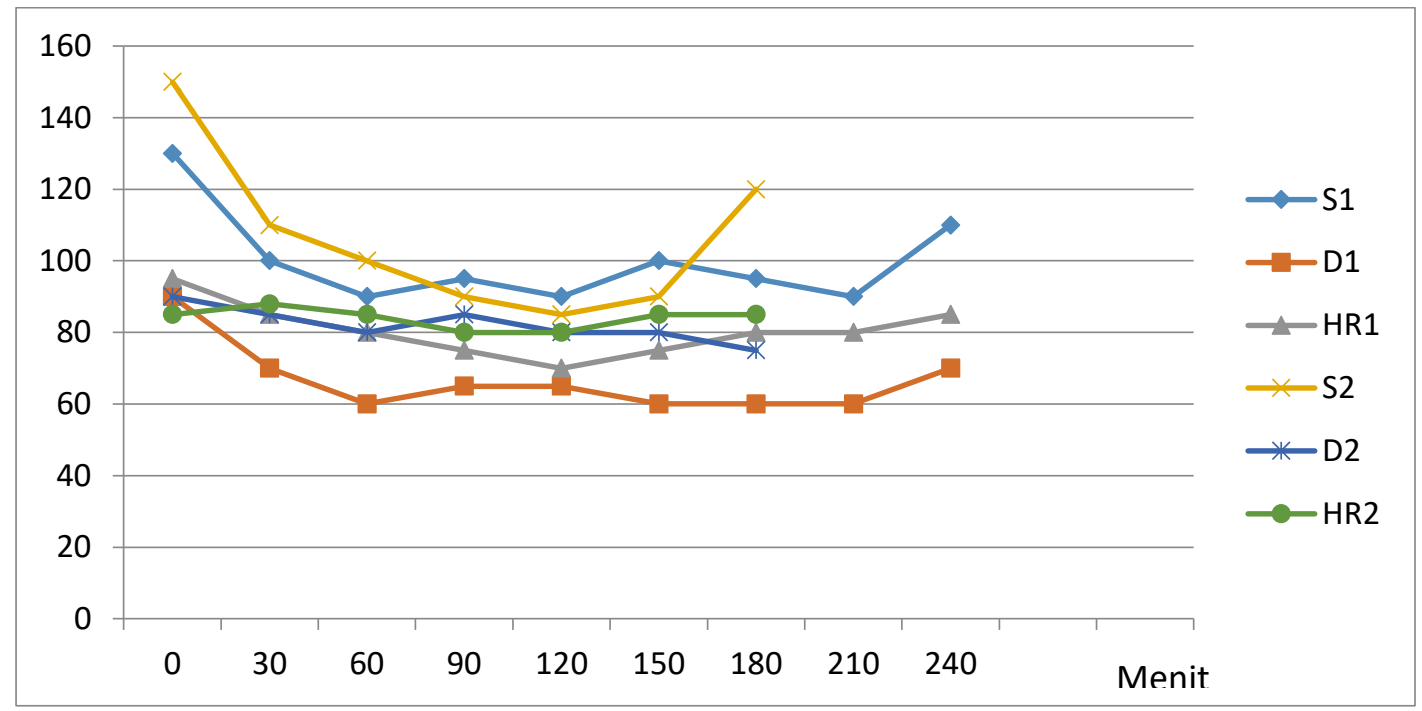

Grafik 1. Tekanan darah dan laju jantung selama operasi

Keterangan:

$\mathrm{S}$ : sistolik , D : diastolik, HR : laju jantung

1 : Pasien 1, 2 : Pasien 2

Satuan sistolik dan diastolik mmHg, laju jantung : $\mathrm{x} /$ menit

Menjelang akhir tindakan operasi, dokter bedah syaraf akan memasang kateter di ruang epidural dengan panjang kateter sekitar $6 \mathrm{~cm}$. Kateter epidural difiksasi di sudut bawah luka irisan, kemudian luka irisan ditutup.

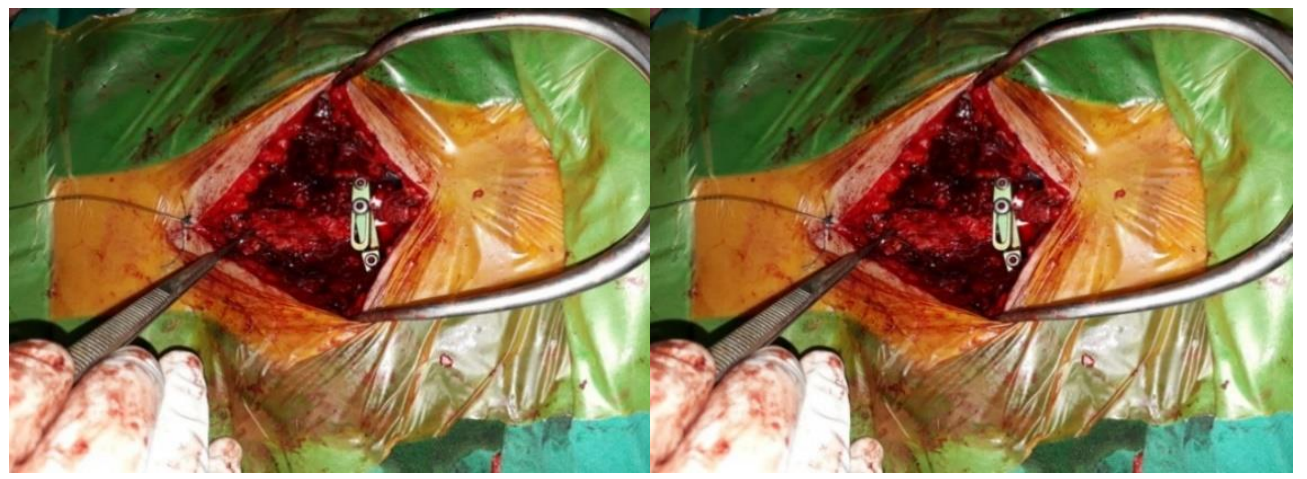

Gambar 1. Pemasangan kateter epidural oleh dokter bedah syaraf pada pasien 1 


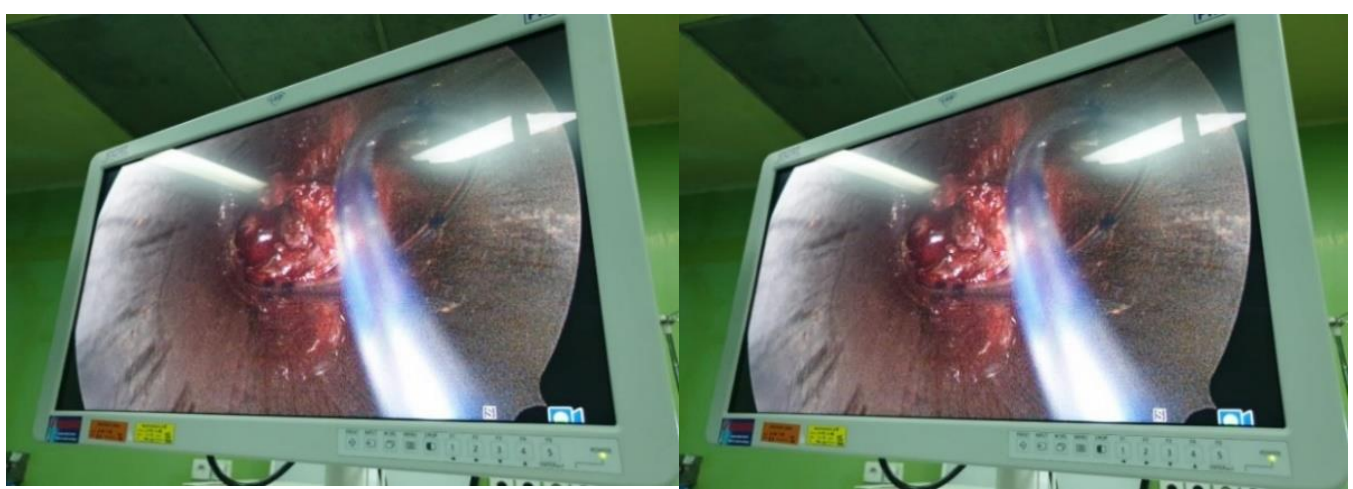

Gambar 2. Pemasangan kateter epidural oleh dokter bedah syaraf pada pasien 2

Setelah luka operasi ditutup, bupivakain $0,125 \%$ bolus $10 \mathrm{ml}$ disuntikan lewat kateter epidural sesaat setelah pasien ditelentangkan. Nyeri pascaoperasi dikelola dengan memberikan bupivakain $0,125 \%$ kontinyu lewat kateter epidural dengan bantuan syringe pump $3 \mathrm{ml}$ / jam. Pasien juga mendapatkan paracetamol $1000 \mathrm{mg}$ tiap 6 jam infus dilanjutkan per oral bila kondisi memungkinkan. Bila pasien masih nyeri akan diberi rescue analgetic bolus fentanil $100 \mu \mathrm{g}$.

Penilaian nyeri pascaoperasi menggunakan NRS. Pertama kali pasien sadar dan dapat memberikan keterangan skor nyeri dianggap titik jam 0 . Skor nyeri berikutnya dinilai pada jam ke 6 , 12, 18, 24, 36, 48. Tekanan darah, laju jantung, dan efek samping dicatat.

\section{Hasil pemantauan pascaoperasi}

Pascaoperasi kondisi kedua pasien stabil tak ada keluhan. Pasien tidak meminta rescue analgetik selama 48 jam.

Tabel 8. Nilai NRS pascaoperasi

\begin{tabular}{lcccccccc}
\hline Hal / Jam & 0 & 6 & 12 & 18 & 24 & 30 & 36 & 48 \\
\hline Pasien 1 & 2 & 2 & 2 & 2 & 1 & 1 & 1 & 1 \\
Pasien 2 & 2 & 2 & 1 & 1 & 1 & 1 & 1 & 1 \\
\hline
\end{tabular}

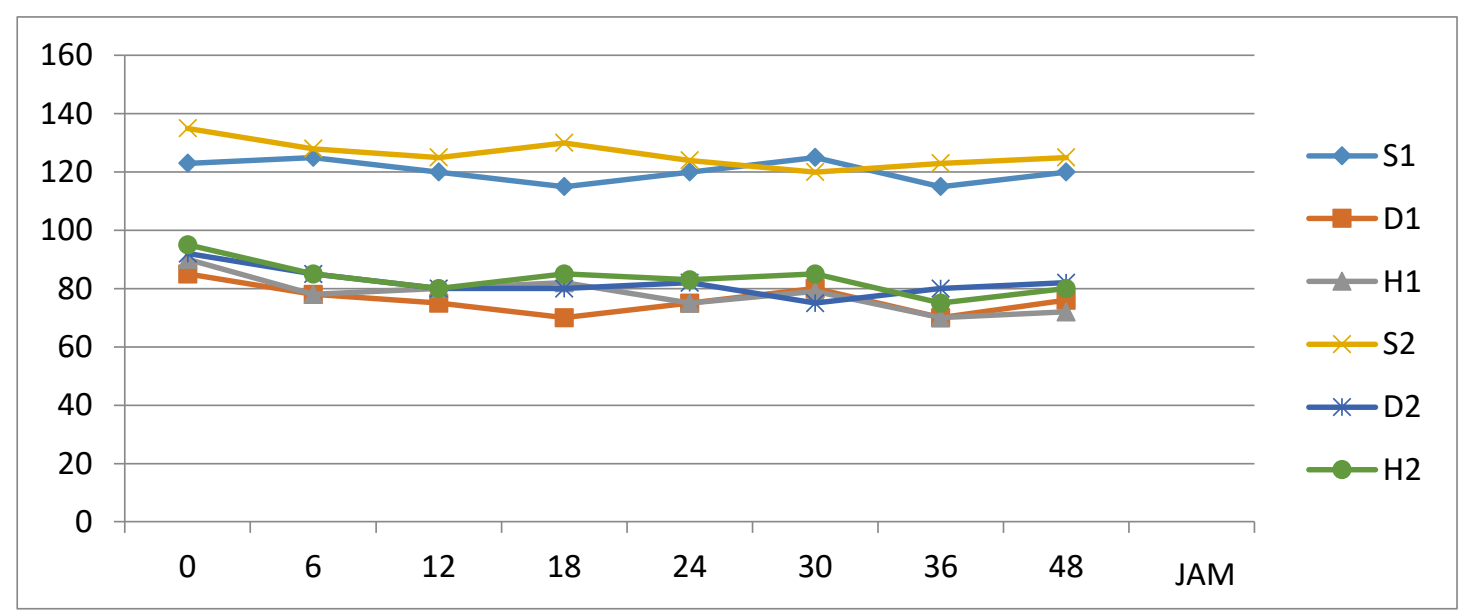

Grafik 2. Tekanan darah dan laju jantung pascaoperasi 
Keterangan:

\author{
S : sistolik , D : Diastolik , H : laju jantung \\ 1 : Pasien 1,2 : Pasien 2 \\ Satuan sistolik dan diastolik mmHg, laju jantung : $\mathrm{x} /$ menit
}

Kedua pasien tidak ditemukan mual muntah. Fungsi motorik dan sensorik tak terganggu pada pasien 2, untuk pasien 1 tak dapat dinilai.

\section{PEMBAHASAN}

Penggunanan teknik anestesi neuroaksial untuk anestesi intraoperatif dan analgesia pascaoperasi untuk operasi tulang belakang masih kontroversial. Beberapa ahli bedah masih menolak penempatan kateter epidural di atau dekat lapangan bedah mereka. Namun demikian lebih banyak bukti yang menunjukkan anestesi regional lebih menguntungkan dibanding kekhawatiran yang bersifat teoritis. Kerusakan neurologis dan angka infeksi didapat sangat rendah ${ }^{3,4}$

Epidural analgesia untuk operasi laminektomi lumbal sebenarnya sudah digunakan sejak tahun 1960. Matheson menggunakan xylocaine $2 \%$ dengan ajuvan adrenalin $1: 300.000$ bolus $20 \mathrm{ml}$ disuntikan di ruang epidural L3 - L4. Matheson menyimpulkan analgesia epidural sangat memuaskan karena medan operasi lebih kering, perdarahan lebih sedikit, pasien pascaoperasi lebih tenang. Kekurangan metode ini terutama pada durasi obat yang terbatas. ${ }^{5}$

Epidural analgesia untuk operasi tulang belakang dapat diberikan sebelum operasi, selama operasi, atau akhir operasi. Obat yang diinjeksikan dapat merupa obat lokal anestesi, opioid, atau kombinasinya. Pemberian obat dapat berupa bolus tunggal, infus kontinyu, atau patient control epidural analgesia (PCEA). Beberapa keuntungan yang didapat berupa skor nyeri yang lebih rendah, kebutuhan opioid lebih sedikit, pemulihan peristaltik usus yang lebih cepat, insiden mual muntah lebih rendah, kehilangan darah durante operasi lebih sedikit, dan tingkat kepuasan pasien lebih tinggi. ${ }^{6,7,8}$

Epidural analgesia untuk menghilangkan rasa nyeri pascaoperasi bedah tulang belakang merupakan metode efektif dan aman. Teknik ini dapat digunakan di semua jenis operasi tulang belakang seperti mikrodisektomi, laminektomi, instrumentasi dengan atau tanpa koreksi, dan koreksi skoliosis. ${ }^{2,6}$ Pada tindakan laminektomi untuk pemasangan timah spinal cord stimulation yang membutuhkan pasien terjaga untuk menemukan parestesia, teknik epidural anestesia terbukti aman dan efektif. ${ }^{9}$ Obat yang digunakan sebagian besar terdiri dari anestesi lokal bupivakain atau ropivakain $0,0625-0,3 \%$ dengan atau tanpa opioid, atau opioid saja. Morfin adalah opioid yang paling sering digunakan diikuti fentanil. Opioid yang diberikan secara epidural menghasilkan analgesia yang lebih baik dibandingkan secara parenteral pada dosis yang sama. ${ }^{10}$ Beberapa adjuvan lain yang lebih jarang digunakan adalah clonidin, metilprednisolon, dan midazolam..$^{2,6}$

Khajavi dkk. membandingkan anestesi umum / general anesthesia (GA) dibanding anestesi kombinasi anestesi umum dan anestesi epidural / combined epidural general (CEG) untuk operasi tulang belakang. Teknik anestesi yng baik harus memiliki onset dan pemulihan yang cepat dan efek yang tak diinginkan minimal. CEG menawarkan beberapa 
keuntungan. Teknik hipotensi yang terkendali dapat mengurangi kehilangan darah yang signifikan (sampai $35 \%$ ). CEG menghasilkan pemakaian agen anestesi lebih sedikit, rasa nyeri pascaoperasi lebih ringan, konsumsi analgetik lebih rendah, dan mual muntah lebih sedikit. ${ }^{11}$

Di RSUP Dr. Kariadi Semarang kami sering menggunakan teknik CEG untuk operasi tulang belakang. Epidural kateter pada awalnya kami pasang sebelum incisi kulit. Kateter diinsersikan sebelum atau sesudah induksi anestesi sebelum incisi. Keuntungan yang kami dapat adalah agen anestesi lebih rendah, hemodinamik stabil sehingga perdarahan lebih sedikit, nyeri pascaoperasi rendah sehingga pemakaian opioid lebih kecil, mual muntah berkurang, dan pasien lebih puas.

Kerugian insersi kateter epidural dan pemberian obat sebelum incisi adalah memerlukan volume obat lebih besar karena biasanya insersi kateter kami lakukan $2-3$ segmen di bawah atau di atas perkiraan batas irisan. Kelemahan lain teknik ini adalah kateter tercabut, perlebaran irisan operasi mengenai tempat insersi kateter sehingga kateter harus dilepas, atau ujung kateter tidak tepat di rongga epidural.

Hasil diskusi kami dengan dokter bedah syaraf memutuskan untuk pemasangan kateter epidural dilakukan oleh dokter bedah pada akhir operasi dan untuk pengelolaan medikamentosanya oleh dokter anestesi. Ujung kateter dengan cara manual atau dengan bantuan endoskopi diletakkan dalam ruang epidural tepat di tengah luka irisan. Dokter anestesi menentukan jenis dan volume obat yang akan dimasukkan. Obat yang sering kami gunakan adalah bupivakain murni konsentrasi $0,125 \%$ atau bupivakain ditambah adjuvan morfin.

Keuntungan pemasangan kateter epidural oleh dokter bedah adalah kateter benar-benar terletak di ruang epidural bukan di tempat lain apalagi di ruang subarahnoid. Ujung kateter dipastikan tidak masuk pembuluh darah. Obat yang diperlukan lebih sedikit. Kerugiannya adalah tidak memberikan analgetik mulai awal operasi sehingga tidak mempengaruhi obat selama anestesi.

Pada kasus ini teknik yang dipakai adalah CEG. Operasi berjalan dengan anestesi umum. Pada akhir operasi dokter bedah syaraf memasang kateter di ruang epidural. Obat yang kami injeksikan adalah bolus $10 \mathrm{ml}$ bupivakain $0,125 \%$ dilanjutkan infus kontinyu bupivakain $0,125 \%$ sebesar 3 $\mathrm{ml} /$ jam. Analgetik lain yang dipakai adalah paracetamol.

Hasil pengamatan dua pasien operasi tulang belakang yang mendapat terapi epidural didapat hasil yang baik. Selama 48 jam penilaian nilai NRS kedua pasien selalu dibawah 3. Hal ini mungkin disebabkan karena penempatan kateter epidural yang tepat sehingga obat yang dimasukkan benar-benar mengisi ruang epidural. Pemberian volume obat epidural $10 \mathrm{ml}$ dilanjutkan $3 \mathrm{ml} /$ jam sudah mencukupi. Pada operasi tulang belakang dengan luka operasi kecil seperti tindakan endospin dapat dipertimbangkan pemberian obat dengan volume yang lebih kecil.

Efek samping mual muntah tidak ditemukan. Hal ini mungkin disebabkan kami tidak menggunakan opioid untuk adjuvan. Fungsi motorik dan sensorik tak terganggu pada pasien 2, untuk pasien 1 tak dapat dinilai karena sudah menderita kelumpuhan. Retensi urin tak 
dapat dinilai karena keduanya dipasang kateter urin.

\section{KESIMPULAN}

Pengelolaan nyeri pascaanestesi menjadi tanggung jawab dokter anestesi dan dokter bedah. Pemasangan kateter epidural menjelang akhir operasi secara manual atau dengan bantuan endoskopi memastikan kateter epidural ditempatkan pada lokasi yang tepat. Epidural analgesia pada operasi tulang belakang terbukti efektif mengelola nyeri pascaoperasi.

\section{DAFTAR PUSTAKA}

1. Carli F, Baldini G . Perioperative Pain Management and Enchanged Outcomes . In : Butterworth JF , Mackey DC , Wasnick JD, ed. Morgan \& Mikhail Clinical Anesthesiology. Fifth ed. New York : McGraw-Hill ; 2013 : 1102

2. Kumar RJ , Menon KV, Ranjith TC. Use of epidural analgesia for pain management after spinal surgery. Journal of Orthopaedic Surgery. $2003 ; 11(1): 67-72$

3. Benyahia NM, Vester A, Saldien V , Breebaart M , Sermeus L, Vercauteren M. Regional anaesthesia and postoperative techniques for spine surgery. Rom $\mathrm{J}$ Anaesth Int Care. $2015 ; 22: 25-33$

4. Mergeay M, Verster A, Van Aken D, Vercauteren M. Regional versus general anesthesia for spine surgery. A comprehensive review. Acta Anaesth. Belg.2015;66:1 - 9

5. Matheson D. Epidural anaesthesia for lumbar laminectomy and spinal fusion. Can. Anaes. Soc . $1960 ; 7$ : $149-57$

6. Benyahla NM, Breebaart $\mathrm{M}$, Sermeus L , Vercauteren $M$.
Regional analgesia techniques for spine surgery: a review with special reference to scoliosis fusion. Journal of spine . $2015: 4-11$

7. Hussien EMM, El Nasr Mohammed GS, El Shaer ANE, Abdelaziz AA , Moharram AA. Efficacy of sacral epidural blockade with bupivacaine versus morphine as pre-emptive analgesia for lumbar laminectomy surgeries. Ain-Shams J Anesthesiol.2016; 9: $260-6$

8. Schroeder KM, Zahed C, Andrei AC , Han S , Ford MP , Zdeblick TA. Epidural anesthesia as a novel anesthetic technique for anterior lumbar interbody fusion. Journal of Clinical Anesthesia. 2011 ; 23: 5216

9. Perez MLG, Badenes R, March GC , Bordes V , Belda FJ. Epidural anaethesia for laminectomy lead placement in spinal cord stimulation. Anesth Analg. 2007; 105:1458 -61

10. Daneyemez LLS, Kurt E, Canakci Z, Gezen F, Suer H, Pain control following lumbar laminectomy : comparison of epidural morphine and morphine plus bupivacaine. Tiirkish Neiirosiirgery. 1999 ; 9: 64 $-67$

11. Khajavi MR, Asadian MA, Imani F , Etezadi F , Moharani RS, Amirjamshidi A. General anesthesia versus combined epidural/general anaesthesia for elective lumbar spine disc surgery : A randomized clinical trial comparing the impact of the two methods upon the outcome variables. Surgical Neurology International. 2013; 4:105 